Hegedüs Mihály

\title{
A korrupció és a rejtett gazdaság hatásai a kis-, és középvállalkozó szektor müködésére
}

Hegedüs, Mihály:

The Impact of Corruption and Hidden Economy on the Operation of the SME Sector

Corruption is a complex phenomenon related to hidden economy, which is also a barrier to economic development and hinders the outbreak from the crisis. Corruption is becoming a more sophisticated instrument of hidden economies and is present in every country parallel to the ever intense acceleration of our globalized world. Its extent depends on, among other things, economic disparities, social deformations, unequal burden-sharing, the rather ingenious forms of tax evasion, social morality, the country's economic development, controlling mechanism and, more importantly, the subtle relations of economic crime with the prevailing powers. Hidden economy and corruption are interrelated phenomena.

Uneven economic development, unemployment, social insecurity, contradictions of the legal regulations, and lack of transparency all provide an incentive to the violation of ethical business practices, the exploitation of the benefits of economic crime, the reinvestment of such profits into the business sphere and the appearance of corruption in the political decision-making. Corruption is a social symptom, a subsistence constraint, a deviant form as well as a status security instrument, the mild (moral) judgment of which encourages participation in the hidden economy and economic crises. If the state or the politics seeks to influence the development of the economy and assumes excessive responsibility or procurer function, it diminishes the principle of public burdens and supports the expansion of corruption and the operation of hidden economy at the same time.

Keywords: corruption, hidden economy, taxation

\section{ÖSSZEFOGLALó}

A korrupció, a rejtett gazdasággal összefüggő összetett jelenség, ami egyben a gazdasági fejlődés gátja, és a válságból való kitörés korlátja. A korrupció, a rejtett gazdaság egyre kifinomultabb elkövetési eszköze, globalizált világunk egyre intenzívebb gyorsulásával párhuzamosan van jelen a világ valamennyi országában. Mértékét a gazdasági aránytalanságok, a társadalmi deformációk, az egyenlőtlen teherviselés, az adófizetést megkerülő „kreatív” eszközök igénybevételi lehetősége, a társadalom erkölcsi érzéke, az ország gazdasági fejlettsége, az ellenőrzés rendszere, a gazdasági bűncselekmények szövevényes, a mindenkori hatalommal történő viszonya jelentős mértékben befolyásolja.
A rejtett gazdaság és a korrupció egymásra ható jelenség. A gazdasági növekedés hullámzása, a munkanélküliség, a létbizonytalanság, a törvényi szabályozások ellentmondásai, az ellenőrzés koordinációs hiánya ösztönzőleg hat az etikus üzleti magatartás megszegésére, a gazdasági bűncselekményből származó előnyök kihasználására, a megszerzett jövedelem vállalkozási szférába történő visszaforgatására, a korrupció a politikai döntéshozatalban történő megjelenésére.

A korrupció egyszerre szociális jelenség, megélhetési kényszer, egy deviánsforma, egy státuszbiztosító eszköz is, amelynek enyhe társadalmi (erkölcsi) megítélése ösztönöz a rejtett gazdaságban, valamint a gazdasági bűncselek- 
ményekben történő részvételre. Ha az állam, a politika a gazdaság fejlődésének irányát befolyásolni igyekszik, és túlzó feladatátvállalást és megrendelő szerepet vállal, azzal csorbítja a közteherviselés elvét, egyben támogatja a korrupció térnyerését, a rejtett gazdaság müködését.

Kulcsszavak: korrupció, rejtett gazdaság, adózás

\section{Bevezetés}

A gazdaság növekedését gátló tényezőinek meghatározása, a növekedés stratégiájának kidolgozása a környezet elemzésén túl a korrupció, a rejtett gazdaság múködésének feltárását igényli. A rejtett gazdaság múködése, mértéke összefüggésben áll a gazdaság főbb szereplőinek motivációival, etikai magatartásukkal, az egyes gyengitő-erősítő tényezők mértékével, az állam számon kérő, megengedő, jogalkotó szerepével. A korrupció egyszerre szociális jelenség, megélhetési kényszer, deviáns jelenség, hivatali visszaélés, státuszbiztosító eszköz, működési rendszer krízis, amelynek esetleges enyhe társadalmi (erkölcsi) megítélése ösztönöz a rejtett gazdaságban, valamint a gazdasági bűncselekményekben történő részvételre.

Az államnak a gazdaság múködése területén történő túlzott szerepvállalása, aktív politikai szemszögből történő befolyásolása, fejlődésének irányát meghatározó, működtető, feladat-átvállaló és megrendelő szerepe, a kontrollkörnyezet hiányosságai, a feltárás alacsony kockázata csorbítja a közteherviselés elvét, támogatja a korrupció térnyerését, a rejtett gazdaság müködését, amely függőséghez, tisztességtelen árversenyhez, egyes gazdasági ágazatok elsorvadásához, a jogállamba vetett bizalom megrendüléséhez vezet.

A korrupció társadalmi -, gazdasági következményekét a rejtett gazdaság kiegészítő, erősítő, összekapcsoló szerepe a gazdasági fejlődéssel együtt változik. Láthatatlan múködése a társadalom etikai mércéjétől függően válik láthatóvá és a gyakorlatban elfogadott, mindennapi cselekvéssé.
A korrupció türése, a gazdasági folyamatokban való részvétele növeli a visszaélések feltárásának kockázatát, gyengíti a társadalom etikus múködésének alapjait, erősíti a rejtett gazdaság működését. A piac múködési zavarait kihasználva egyre növekszik a gazdasági bűncselekmények globalizációja, módszerek kreatív, kifinomult igénybevétele.

A korrupció beavatkozik a természetes gazdasági folyamatok automatizmusába, a kormányzati mechanizmusok ellenőrző, erősítő szerepük helyett olykor át nem gondolt beavatkozásaikkal korlátozzák a piaci folyamatokat, eltérítik a piac számára visszajelzésként szolgáló információkat, a termelést és beruházást élénkítő intézkedéseiket a mindenkori kormányzó párt szimpátia alapján határozzák meg. A korrupció és a politika összefonódásaként a gazdaság múködtetése az érdekcsoportok hálójából nem tud kitörni.

A korrupció jellemzője, hogy a központosított, autokratikus berendezkedésű ország esetében a rejtett gazdaság mértéke jelentős, a gazdaság működésének mindennapjait átszövi a megvesztegetés, az államigazgatási mechanizmusok bomlási folyamatai.

A társadalom egyes rétegei a fennmaradásuk érdekében korrupció alkalmazására, illetve a rejtett gazdaságban való részvételre kényszerülnek. A gazdasági átrendeződések, a politika aktív társadalom átalakító szerepe jelentős hatást gyakorol a jog, és a gazdaság összefüggéseire, olykor pótlólagos adóként befolyásolja a piac, a politika, a társadalom múködését.

A túlzott adóterhek, a bürokratikus szabályozás miatt az életszínvonallal összefüggő szükségletek mellett előtérbe kerülnek a tiltott tevékenységekkel, kilátástalan helyzetekkel kapcsolatos motivációk. A kontroll hiánya, az ellenőrzési rendszerek összekapcsolásának elégtelen volta, a független külső ellenőrzés leépítése teret enged a korrupció, a rejtett gazdaság működésének, globalizációjának.

Az összetett jogalkotási folyamat számossága, azok gyakori módosulásai, az egyes lobbi tevekénységek hatásainak megjelenése a jogalkotási folyamatokban átláthatatlanná, ter- 
vezhetetlenné teszik a gazdasági folyamatok alakulását, a jövedelmezőség, megtérülés számítását.

A gazdasági visszaélések felderítési mutatóinak alacsony mértéke, a cselekménnyel okozott károk növekedését, a társadalmi közhangulat romlását, az egyenlőtlen teherviselést vonja maga után. A tudományos és az állami szféra szakértői között nem mutatkozik nézetelérés a rejtett gazdaság feltárásának szükségesség tekintetében, azonban a megelőzés tekintetében számos elemzés ellenére számottevő eredményt hazánkban nem sikerült eredményt elérni.

\section{ANYAG ÉS MÓDSZER}

Kutatásom a „Korrupció és a rejtett gazdaság hatásai" tanulmány során felvetett kérdésekre adandó válaszok megfogalmazása kapcsán készült, amely során választ kerestem arra a feltételezésre, hogy a korrupció mértéke, a rejtett gazdaság működése mennyiben veszélyezteti az egyes országok gazdasági teljesítőképességének növekedését.

Jelen tanulmányban vizsgálom, azt vizsgálom miként hat egymásra politika és a gazdaság intézményrendszere, $\mathrm{s}$ a milyen hatással van a kis-, és középvállalkozó szektor működésére, a gazdaság teljesítményére.

Vizsgálom a gazdasági visszaélések típusait, a károk mértékét, a gazdasági visszaesésben betöltött szerepüket, társadalmi és etikai kérdéseket, az elkövetett cselekmények országonként eltérő megítélésének okait.

Elemzésem alapját a rejtett gazdaságról, korrupcióról megjelent hazai és nemzetközi tanulmányok, saját magyarországi és nemzetközi gyakorlatban eltöltött tapasztalatok, a magyarországi székhellyel rendelkező társas vállalkozások által a 2010-2011-es évekre benyújtott társaságiadó-bevallásokról készített NAV gyorsjelentések, valamit az OPTEN 2010, 2011-es adatbázis elemzése képezte. Jelen tanulmányban annak terjedelme és a teljes kutatás lezáratlansága miatt részeredményeket közlök.

\section{EREDMÉNYEK}

\section{A korrupció definiálásának problémái}

A korrupciót a modern világ egyik legfóbb gazdasági problémája, az egész világot tekintve a vállalatok 40 százaléka kénytelen megvesztegetési pénzeket fizetni. [Szvetlana 2010:116].

A korrupció jelensége évezredek óta jelen van az államigazgatási, társadalmi rendszerekben, kiváltó okait, megjelenési formáit tekintve összetett, sokrétű jelenség.

Lackó [2008:3] legegyszerűbb definícióként történő megfogalmazása szerint a korrupció nem más, mint a közhatalommal való visszaélés magánnyereség céljából.

A közgazdaságtan a 18. századig a morálfilozófia része volt, mégis a korrupcióra, mint szociális jelenségre vonatkozó univerzális definíciót nem sikerült kidolgoznia, amelynek oka a korrupció megjelenésének történelmi, vallási gyökereiben keresendő, illetve a társadalmi jelenség különböző nézőpontból történő vizsgálatából ered.

A klasszikus közgazdaságtan emberképe racionális egoista, döntéseiket nem irányítják morális szempontok, a korrupciót természeti és a pozitiv törvények között fennálló ellenmondás egyik következményeként fogják fel. A korrupció és a politika összekapcsolása a centralizált államok kialakulásából eredeztethető, amelyben a politika a gazdasági életet meghatározó „árúvá" válik. A korrupciót, mint társadalmi jelenséget megközelítő vizsgálatok arra hívják fel a figyelmet, hogy a közszolgák megvesztegetése, megvásárlása mellett a jelenség megrontó, tönkretévő, leromboló, a társadalom politikai szerkezetét deformáló etikai szerepe nem függ az egyes megközelítés kereteitől. 
A szociológia elméletek szerint a korrupció az elfogadott normáktól történő eltérést, etikai megközelítésben írott és íratlan szabályok megsértését, közgazdasági értelemben a "termék” árában megjelenő extra adót jelenti, míg jogtudomány szerint a hivatali hatalommal való viszszaélést, megvesztegetést foglalja magába.

Gazdaságelméleti szempontból a korrupció nem más, mint termelés nélküli profitszerzés, szolgáltatást tekintve anyagi és nem anyagi javak átadása olyan eszközök vagy szolgáltatások megszerzése érdekében, amelyek az igénybevevő számára egyébként nem, vagy csak kedvezőtlenebb feltételekkel lennének elérhetőek.

A korrupció, mint a rejtett gazdaság egyik befolyásoló eleme torzítja a közszolgáltatási szektor fő funkciót, erősíti a társadalmi elit gazdaságban történő részvételét, csereként történő felhasználása a piac elemeinek torzításán túl elosztó rendszerként is funkcionál, alapja a nemzetek hanyatlásának, a társadalmi korlátok kialakulásának, a gazdasági növekedés alacsony szintjének.

\section{Az adóráták és a korrupció hatásai}

A korrupció mértékét a gazdasági folyamatokba történő állami beavatkozás mértéke befolyásolja. A rejtett gazdaság múködését a közgondolkodás, az adóráták magas mértékével, mint okokozati összefüggésként azonosítja.

A rejtett gazdaság kialakulását fokozhatja ugyan az önfoglalkoztatás, a személyi jövedelmet terhelő adók mértéke, de az önmagában nem ok a korrupció és a rejtett gazdaság kialakulására. A vállalkozások egy része az adóterhelés mértékét tartja a válság egyik okozójának és a kitörési lehetőség egyik gátjának.

\section{1. táblázat: Adóbevételek GDP-hez mért értéke (\%)}

\begin{tabular}{|l|l|l|l|l|l|l|l|}
\hline & 2005 & 2006 & 2007 & 2008 & 2009 & 2010 & 2011 \\
\hline Ausztria & 42,1 & 41,5 & 41,7 & 42,7 & 42,4 & 41,9 & 42,0 \\
\hline Belgium & 44,8 & 44,4 & 43,9 & 44,2 & 43,4 & 43,8 & 44,1 \\
\hline Bulgária & 31,3 & 30,7 & 33,3 & 32,3 & 29,0 & 27,5 & 27,2 \\
\hline Csehország & 35,7 & 35,3 & 35,9 & 34,4 & 33,4 & 33,5 & 34,4 \\
\hline Dánia & 50,8 & 49,6 & 48,9 & 47,8 & 47,8 & 47,4 & 47,7 \\
\hline Finnország & 43,9 & 43,8 & 43,0 & 42,9 & 42,8 & 42,5 & 43,4 \\
\hline Franciaország & 43,8 & 44,1 & 43,4 & 43,2 & 42,1 & 42,5 & 43,9 \\
\hline Egyesült Királyság & 35,8 & 36,6 & 36,1 & 37,6 & 34,6 & 35,4 & 36,1 \\
\hline Lengyelország & 32,8 & 33,8 & 34,8 & 34,3 & 31,8 & 31,8 & 32,4 \\
\hline Magyarország & 37,4 & 37,3 & 40,4 & 40,3 & 40,1 & 37,9 & 37,0 \\
\hline Németország & 38,3 & 38,6 & 38,7 & 38,9 & 39,3 & 37,9 & 38,7 \\
\hline Olaszország & 40,1 & 41,7 & 42,7 & 42,7 & 43,0 & 42,5 & 42,5 \\
\hline Románia & 27,8 & 28,5 & 29,0 & 28,0 & 26,9 & 26,7 & 28,2 \\
\hline Szlovákia & 31,3 & 29,3 & 29,3 & 29,3 & 28,9 & 28,1 & 28,5 \\
\hline Svédország & 48,9 & 48,3 & 47,3 & 46,4 & 46,5 & 45,4 & 44,3 \\
\hline
\end{tabular}

Forrás: Commission services 2012, szerkesztett változat 
$A z$ adóterhelés mértékét jelzi az adóbevételek GDP-hez mért aránya. A magasabb adóék magasabb adóbevételi arányokkal jár együtt. $A$ legmagasabb adóterhelést Dánia mondhatja magáénak 2011-ben, 47,7\%-al, amelyet Svédország 44,3\%-al, majd Franciaország követ 43,9\%-al. A sor végén - a táblázatban nem jelzett- Törökország áll 25\%-al, míg Svájc 28,5\%-a megegyezik Szlovákia 28,5\%-os arányával.

Magyarországon a válság kezdő időpontját jelző 2007- évhez képest az adóból származó bevételek 3,4\%-al, Svédország 3\% -al, Szlovákiában 1,2 \%-al, Csehországban 0,6\%, az Egyesült Királyságban pedig $0,3 \%$. csökkentek, azaz nem mindenkit érintett egyformán a válság. Az eltérés a válságra adott válaszok, reakciók, a választott kiútkereső módszerek elfogadásában, azok bevezetésének sikerességében keresendő.

Az adóterhelés mértének és irányának megállapításához társadalmi közmegegyezés szükséges, amely egyenes következménye lehet a befizetési hajlandóságnak.

$A z$ adóterhelések irányuktól, módszerüktől függően jelentős hatással vannak a gazdaság fejlődésére. Észak-Európában az általánosan magas adóterhelés ellenére a társadalmi közmegegyezés miatt szívesen fizetnek adót, mert a befizetők tisztában vannak felhasználásuk mértékével, az elosztások irányaival. A fejlett nyugati országokban az intézményrendszer a természetes fejlődés eredményeképp alakult ki, kapcsolódott a társadalmi tudat sajátosságaihoz, a gyakorlathoz, a tradíciókhoz. Az intézményrendszerek nem formálisak, hatékonyságokat az állami beavatkozások nem korlátozzák.

Kelet és dél Európában a kép árnyaltabb, alacsonyabb az adóterhelés, de a felhasználás transzparenciája nem mindenki számára világos és hozzáférhető. A hatalom sok tekintetben nem az elsődleges feladataira koncentrál, az ellenőrző szervezetek és ágazatok munkáját különböző érdekcsoportok nagymértékben be- folyásolják. A vállalkozások nagy száma, kényszervállalkozási jellegük, a munkát terhelő adók mértéke arra ösztönzi a vállalkozók egy részét, hogy a törvények, normák megszegésével biztosítsák túlélésüket.

A centralista törekvések az uralkodó társadalmi réteg és egyes lobbi szervezetek véleményének, befolyásának megfelelően alakítja a törvényi előírásokat, amely végül a társadalmi közöny érvényesüléshez, a modernizációs kitöréshez szükséges energia elvesztéséhez vezet.

Lackó [2008:11] szerint az adóráták és a korrupció interakcióját megtestesítő indikátor (amelyet akár tekinthetünk egy olyan adórátának, amely szúken értelmezett, hagyományos adóék mellett tartalmazza a visszahúzó gazdasági környezetből, korrupcióból következő költségeket is) azt az összefüggést sejteti, hogy növekedése egy bizonyos szintig növeli az adóbevételt, de ezen túlhaladva hatása megfordul, s innen növekedése már csökkenti a beszedett adók volumenét.

A válságból történő kitörési pontokra eltérő reagálások születtek. Egyes országok, így Magyarország is a munkabéreket terhelő adók helyett a fogyasztási típusú adók felé fordult.

Az összes magyar adóbevétel 45,8 százalékát a közvetett adók teszik ki, ennél csak Romániában és Bulgáriában nagyobb ez az arány. A fogyasztás adóterhelése 2011-ben átlagosan 26,8 százalékos volt Magyarországon, ami uniós összevetésben a negyedik legnagyobb arány, a munkát pedig átlagosan 38,4 százalékos elvonás terhelte, ami a nyolcadik legmagasabb hányad az unió egészét tekintve. A munkát terhelő átlagos elvonás uniós szinten 35,8 százalék.

A magyar általános áfa-kulcs 2009-ben 20ról 25 százalékra, 2012-ben pedig 27 százalékra emelkedett, emellett viszont több termék és szolgáltatás kedvezményes, 18 vagy 5 százalékos áfa kulccsal adózik.

2008 óta 17 uniós tagállam emelte az általános forgalmi adó kulcsát,- köztük Magyarország 
a legnagyobb mértékben- 7 százalékponttal, Romániában és Spanyolországban 5-5, Görögországban pedig 4 százalékponttal emelkedett a forgalmi adó kulcsa ugyanebben a periódusban.

$\mathrm{Az}$ irányváltást bírálók kiemelik, hogy az adóterhelés irányának változása akkor lehetne helyes, ha a munkabéreket, terhelő adómegtakarításokat beruházásokra, államkötvények vásárlására, fogyasztási javak vásárlására fordítanak.

A közvetett adóformákból befolyó bevétel mintegy fele, a GDP 8,5 százalékának megfelelő összeg a forgalmi adókból folyt be a magyar költségvetésbe.

Az infláció ugyan csökkent, de ez a kereslet visszaszorulása miatt van, azaz a fogyasztás az alapvető élelmiszerek tekintetében növekedett, a beruházások, építések tekintetében stagnált illetve csökkent.

2008-ban és 2009-ben a válság miatt a tagállamok adóbevételi abszolút értelemben és GDP-arányosan is csökkentek, majd ezt követően ismét emelkedni kezdtek, jelentősen emelkedtek a közvetett adókból származó bevételek. Általánosan 2011-tôl a munkát terhelő adókból is ismét egyre több pénzhez jutnak a tagállamok. Az eurózóában jelentősebb, azon kívül pedig némileg kisebb mértékben emelkedett a jövedelemadó legfelső kulcsa, 20102011-ig viszont meredeken csökkent a társasági adókulcs, amely most átlagosan 23 százalék körüli.

Lackó [2008:12] szerint az adócsökkentés adóbevételt növelő hatása még korrupcióval kombinált interakciós adó-változó esetén sem valósul meg.

Az adórendszer kialakításához, formálásához társadalmi közmegegyezés szükséges, nem müködhet egyszerre államháztartási bevételként, növekedést serkentő elvonásként, szociális juttatásként, rejtett gazdaság és korrupció csökkentő tényezőként, társadalmi lét alakítóként.

Általában a munkajövedelmeket terhelő ma- gas adók esetében kiugróan növekszik a rejtett gazdaságaránya, azonban ez többnyire a dél-, és közép-európai országok esetében tapasztaljuk, amelyetTörökország, Magyarország, Lengyelország, Szlovákia, Görögország,

Csehország, Olaszország, Oroszország esetében esetében a számos kutatás igazolt. [VISA 2013; Szvetlana 2008]

Lackó [2008:13] vizsgálata az indirekt adóráta tekintetében is rámutat arra, hogy a magas adóék magas korrupcióval párosulva csökkenti az adóbevételeket, amely végső soron ellensúlyozza az adóráták adóbevételt növelő hatását.

Tapasztalataim azonban ellen mondanak azon megállapításoknak, amely szerint az általános forgalmi adók alapja kevésbé titkolható el, mint a munkát terhelő adók alapja.

A rejtett gazdaság tipikusan az a terület, ahol nincs számlakibocsátás, azaz nincs áfa adóalap sem. A láncügyletek során elkövetett adócsalások esetében a teljesítés helyének megváltoztatásával áfa mentesen állítják ki a számlát, azaz van adóalap, de nincs adó.

A fiktív ügyleteknél van számla és van adóalap, de nincs gazdasági esemény, amely miatt nem létező gazdasági esemény után kerül az áfa visszaigénylésre. Az egyes gazdasági események igénybevevőjének megváltoztatása esetén is van adóalap és indirekt, adó, de nem az eredeti szolgáltatást, termékértékesítést nyújtó él visszaigénylési jogosultsággal, hanem közbeiktatott vállalkozás.

A legjelentősebb költségvetést érintő csalások, már a mértéke miatt is az indirekt adó tekintetében fordulnak elő.

Magyarország a gabonakereskedelem mellett a hatósági engedélyköteles építőipari, a cukor kereskedelem területén kérte a fordított áfa bevezetésének lehetőségét. Az informatikai termékek, a tojás, a hús közösségi „értékesíté$\mathrm{se}^{\prime \prime}$ területén megjelenő áfa csalások mértéke arra figyelmeztet, hogy a rejtett gazdaság és a korrupció is gyors irányváltásra képes. 
Az Európai Bizottság tanulmánya [EUobserver 2013.09.19] szerint mintegy 193 milliárd eurónyi pénzt vesztettek az uniós tagállamok 2011ben áfa csalások következtében.

$A z$ áfa csalások GDP-hez viszonyított aránya Románia, Görögország, Litvánia, Lettország tekintetében a legjelentősebb mértékű, míg a leginkább érintett államok Olaszország (36) milliárd, a franciák (32), a németek (27), a britek (19) és a spanyolok (15) milliárd euróval.

\section{A rejtett gazdaság}

A rejtett gazdaság terjeszkedése miatt a költségvetés bevételei csökkennek, az állam az adóbevételek szinten tartása érdekében az adótörvények állandó korrekciójára kényszerül. A túlzott adóterhek és túlzott szabályozás azonban tovább erősíti a rejtett gazdaság keletkezését, legfeljebb annak irányát változtatja meg, a kormányzati mechanizmusok pedig károsan korlátozzák a piaci mechanizmusokat. A rejtett gazdaság megteremti azon pénzügyi eszközök, amelyekkel a korrupció során felhasználva a számukra kedvező döntéseket befolyásolhatják.

A rejtett gazdaságban a versenyképesség nem mérhető, munkaerő költsége nem kalkulálható, tettenérése a jelentős készpénzforgalom, a flexibilitás miatt számos nehézségbe ütközik. Az etikus gazdasági tevékenység végzése azt feltételezi, hogy a felek szerződéseiket megtartják, a jogi megkötések mellett a tevékenységet az üzleti lelkiismeret, a verseny tisztaságában és mások tisztességében vetett hit vezérli. A globalizáció következtében létrejövő bővülő termékválaszték gyors technológiai váltást, hatékonyság növelését feltételezi. A hitel és tőkeszegény vállalkozások esetében a technológiai váltást a korrupció és a rejtett gazdaság működtetése helyettesíti, amely során a munkaköltséget terhelő adók, illetve a termékértékesítést terhelő indirekt adók megspórolhatók.

A jellemzően kelet és dél európai országok esetében a hagyományok, beidegződések, infrastruktúrák elhanyagolt volta, tőkeszegénység, politikai és társadalmi intézményrendszer korlátokként áll a rejtett gazdaság és korrupció visszaszorításával szemben megteendő intézkedésekkel.

2. táblázat Korrupcióérzékelési index (CPI) 2012 EU \& Nyugat-Európa

\begin{tabular}{|c|l|c|}
\hline $\begin{array}{c}\text { Ország he- } \\
\text { lyezés }\end{array}$ & Ország /Terület & $\begin{array}{c}\text { CPI } 2012 \text { Pont- } \\
\text { szám }\end{array}$ \\
\hline 1 & Dánia & 90 \\
\hline 1 & Finnország & 90 \\
\hline 4 & Svédország & 88 \\
\hline 6 & Svájc & 86 \\
\hline 7 & Norvégia & 85 \\
\hline 13 & Németország & 79 \\
\hline 17 & Egyesült Királyság & 74 \\
\hline 22 & Franciaország & 71 \\
\hline 25 & Ausztria & 69 \\
\hline 37 & Szlovénia & 61 \\
\hline 41 & Lengyelország & 58 \\
\hline 46 & Magyarország & 55 \\
\hline 48 & Litvánia & 54 \\
\hline 54 & Csehország & 49 \\
\hline 54 & Lettország & 49 \\
\hline 62 & Szlovákia & 46 \\
\hline 66 & Románia & 44 \\
\hline 72 & Olaszország & 42 \\
\hline 75 & Bulgária & 41 \\
\hline 94 & Görögország & 36 \\
\hline & & \\
\hline
\end{tabular}

Forrás: http://www.transparency.org/cpi2012 szerkesztett változat

A közjavakból történő részesüléssel szemben évtizedek óta fennálló alacsony befektetés emléke továbbra is a korrupció fenntartására, a rejtett gazdaságban történő részvételre ösztönöz.

A munkanélküliség miatt a vállalkozók kényszervállalkozóvá válnak, és a rejtett gazdaság szektorába tevékenykednek. A magyar gazda- 
ságot jellemző mikrogazdasági vállalkozások számaránya nem indokolt, a jelenlegi struktúrában, a nagyfokú verseny, a piac felvevőképessége és meglévő árszínvonala miatt az adók kitermelése korlátozottan lehetséges. A közvetlen és közvetett adók magas rátája önmagában nem indokolja a rejtett gazdaság kialakulását, azt valamennyi környezeti tényező együttes befolyásának eredménye.

A gazdaság szereplőit terhelő adók terhe jobban kapcsolódik a rejtett gazdasághoz, a korrupcióhoz, mint az adóráták nagyságához.

Magyarország a középmezőnyben helyezkedik el, míg az észak-európai jellemzően a korrupciós táblázat elején állnak, azaz szinte alig fedezhető fel korrupció. A felmérés azt bizonyítja, hogy a korrupció és az adóterhelés között csekély összefüggés fedezhető fel, az adott országok az adóbevételek a szociális és társadalmi intézmények működtetésére az adóbefizetők szerint optimálisan használják fel.

3.táblázat A rejtett gazdaság a GDP \%-ában

\begin{tabular}{|l|l|}
\hline 2007 & 20,1 \\
\hline 2008 & 19,4 \\
\hline 2009 & 19,9 \\
\hline 2010 & 19,7 \\
\hline 2011 & 19,3 \\
\hline 2012 & 19,0 \\
\hline
\end{tabular}

Forrás: VISA The Shadow Economy in Europe 2013, szerkesztett változat

A VISA The Shadow Economy in Europe 2013es tanulmánya az európai fekete-gazdaságra vonatkozó euróban kifejezett összegek enyhe növekedését mutatja, a GDP-hez viszonyított \%-os érték tekintetében, átlagban folyamatos csökkenés tapasztalható.

A tanulmány szerint a rejtett gazdaság fokozottabb mértékben fordul elő, az építőiparban
(31\%) a nagy és kiskereskedelemben (20\%), a vendéglátóiparban (19\%), a mezőgazdaság és a gyártásban (15\%), míg ingatlanpiac tekintetében mindössze 7\%-ban.

A Transparency International [2012] elemzése szerint Magyarországon tevékenykedő üzletemberek szerint Magyarországon nem, vagy csak rendkívül nehezen lehet korrupciómentesen érvényesülni az üzleti életben. A különböző lakossági és vállalati felmérések, a sajtóelemzések, valamint e kutatás keretében végzett mélyinterjúk egyértelműen alátámasztják, hogy a gazdasági élettel összefüggő korrupciós jelenségek az üzletemberek számára nagyobb problémát jelentenek az üzleti és a közszféra találkozásánál, mint az üzleti szektoron belül.

4. táblázat: A rejtett gazdaság alakulása Európában 2012-ben

\begin{tabular}{|l|c|}
\hline & $\begin{array}{c}\text { Rejtett gazdaság } \\
\text { aránya (\%) }\end{array}$ \\
\hline Ausztria & $7.6 \%$ \\
\hline Bulgária & $31.9 \%$ \\
\hline Csehország & $16.0 \%$ \\
\hline Dánia & $13.4 \%$ \\
\hline Franciaország & $10.8 \%$ \\
\hline Németország & $13.3 \%$ \\
\hline Magyarország & $22.5 \%$ \\
\hline Lengyelország & $24.4 \%$ \\
\hline Románia & $29.1 \%$ \\
\hline Szlovénia & $23.6 \%$ \\
\hline Szlovákia & $15.5 \%$ \\
\hline Egyesült Királyság & $10.1 \%$ \\
\hline Törökország & $27.2 \%$ \\
\hline
\end{tabular}

Forrás: VISA The Shadow Economy in Europe 2013, szerkesztett változat 


\section{A MŰKÖDÉST GÁTLÓ TÉNYEZŐK}

Az önfoglalkoztatói rendszer nehezen regisztrálható,vállalkozások számának alakulása nem tükrözi a gazdaság igényét. (5. táblázat). 2009-re 1.686 e db-ra nőtt a vállalkozások száma, amelyben jelentős számban jelentek meg a tőkeszegény, hitelképtelen kényszervállalkozók, az adócsalási célra létrehozott társaságok.

Nőtt az egyéni vállalkozások száma, amely növekedés többnyire a kényszervállalkozókból, az ügynöki és egyéb munkaviszonyok átrende- támogatást igényelni nem tudnak, az adóregisztrációs eljárás során nem feleltek meg, azaz már a megalapításuk napján múködésképtelenek. A kkv szektor torz szerkezetét jelzi, hogy 2012-ben több mint 38 ezer vállalkozás került felszámolási eljárás alá.

Az 5. táblázat szerint a KSH adatai alapján a múködő vállalkozások száma (Egy adott évben működő vállalkozásnak tekintünk egy vállalkozást, ha az év folyamán volt árbevétele, vagy foglalkoztatottja) 2010. évben 696 680, ebből 384947 a társas vállalkozások száma. A regiszt-

5. táblázat: Működő vállalkozások száma gazdálkodási forma szerint

\begin{tabular}{|l|r|r|r|r|r|r|r|}
\hline \multicolumn{1}{|c|}{ Gazdálkodási forma } & \multicolumn{1}{c|}{2000} & \multicolumn{1}{c|}{2005} & \multicolumn{1}{c|}{2006} & \multicolumn{1}{c|}{2007} & \multicolumn{1}{c|}{2008} & \multicolumn{1}{c|}{2009} & 2010 \\
\hline Korlátolt felelősségú társaság & 114112 & 163475 & 173393 & 183920 & 206333 & 222289 & 239673 \\
\hline Részvénytársaság & 3336 & 3388 & 3457 & 3536 & 3728 & 3817 & 3898 \\
\hline Szövetkezet & 3954 & 3080 & 2784 & 2466 & 2318 & 2185 & 2152 \\
\hline Jogi személyiségú társas vállalkozás & 124031 & 173661 & 183830 & 194324 & 217127 & 233280 & 250958 \\
\hline Közkereseti társaság & 5970 & 5535 & 5309 & 4950 & 4625 & 4299 & 4027 \\
\hline Betéti társaság & 134169 & 155325 & 156942 & 152243 & 146345 & 137136 & 129165 \\
\hline Jogi személyiség nélküli társas & 141041 & 161122 & 162571 & 157529 & 151345 & 141829 & 133989 \\
\hline vállalkozás & 265072 & 334783 & 346401 & 351853 & 368472 & 375109 & 384947 \\
\hline Társas vállalkozás & 360075 & 372973 & 351745 & 336205 & 332918 & 313887 & 311733 \\
\hline Egyéni vállalkozás & 625147 & 707756 & 698146 & 688058 & 701390 & 688996 & 696680 \\
\hline Vállalkozás összesen & & & & & \\
\hline
\end{tabular}

Forrás: http://www.ksh.hu/docs/hun/xstadat/xstadat_eves/__qvd002b.html, szerkesztett

ződésből ered. A korlátolt felelősségű társaságok a liberalizált társaságalapítási lehetőséggel élve tőkeszegényen jöttek létre, jegyzett tőkéjük az alapítás napján elfogyott, további működésüket a szürkegazdaságban megtermelt jövedelmekből finanszírozták. Az egyes családi vállalkozás keretében megalakított gazdasági társaságok több mint 10\%-nak éves nettó árbevétele nem haladja meg az 500 . e Ft-ot, saját tőkéjük nincs, hitelfelvételre nem jogosultak, rált és a működő vállalkozások száma között eltérés jelzi, hogy a gazdasági társaságok jelentős része alkalmazottat nem foglalkoztat, árbevétele nincs, azaz gazdasági tevékenységet nem folytató vállalkozás.

A működő, új, valódi, megszűnő vállalkozások adatai jelzik a kkv szektor múködését, amely egyúttal az egyik problémája a gazdaság jelenlegi állapotának. A működő vállalkozások közel 90\%-a foglalkoztat 1-4 fö között, amely 
a foglalkoztatás területén mikro-vállalkozások aránytalanul nagy számát mutatja, $s$ rámutat egyúttal a kényszervállalkozások nagy számára is. A 2010-es társasági adó bevallás elemzése során a 348.623 társasági adóbevallást benyújtó vállalkozásból 7.053 gazdasági társaság (az összes társaság $2 \%$-a) foglalkoztat csak 250 fö felett. A mikró vállalkozás jellemzően 1-4-fő közötti alkalmazotti létszámot foglalkoztatnak, minimálbéren jelentik be munkavállalóikat, osztalékot nem vesznek ki, árbevételeik egy részére bevételi számlát nem állítanak ki, a munkabérek egy részét nem a gazdálkodás tevékenységének érdekében elszámolható költségszámlák felhasználásával fedezik.

A szabályozások gyakori változása, a bűncselekmények felderítése, egymásnak ellentmondó, sokszor nem megalapozott ítéletek, a végrehajtások gyengeségei miatt az adócsalók a felelősségre vonást javarészt elkerülik.

A vállalkozások, a tranzakciók, a kapcsolatok számának növekedése, az informatikai felkészültség hiánya, az eltérő adatbázisok használata, a gyakran változó jogszabályok, az ellenőrök felkészültsége, a szakmai és ellenőrző szervezetek közös fellépésének hiánya sem kedvezett a feltárás hatékonyságának.

\section{4. ÖSSZEGZÉS, KÖVETKEZTETÉS}

A kis- és középvállalkozói szektor jelenlegi helyzete, struktúrája, a tőkehiány, a vállalkozás részvényeinek piaci megítélésére, a hitelek-köl- csönök felvétele kapcsán támasztott követelmények teljesíthetősége a gazdaságban végzett tevékenység általános etikai normáinak megkerülésére kényszeríti a vállalkozások egy részét.

A tisztességes elveken nyugvó, etikus üzleti magatartás a gazdaság valamennyi szektorában támogatja. háttérbe szorul; az erkölcsi normák a megélhetési, túlélési kényszer mellett küzdenek az állam kiigazító, beavatkozó szerepével.

A gazdálkodás fenntartási kényszere az információk, a beszámolók, a könyveikben szereplő adatok valóságtól eltérő korrekciójára ösztönöz; az alkalmazott számviteli értékelési eljárások egy része ellentétes a valódiság, következesség, egyedi értékelés számviteli alapelvekkel.

A kontrollkörnyezet hiányosságai, a feltárás alacsony valószínűsége a kockázat nélküli csalások elkövethetőségét

A rejtett gazdaság működése, a korrupció jelenléte okozója a gazdasági visszaesésnek. Az általános etikai normák megkerülésének növekedése már nem csak a vállalkozási szektorban figyelhető meg, hanem jelen van a közéleti döntéshozásban is.

Az etika, bizalom és az adómorál egymással összefüggő, egymásra ható fogalmak, a gazdaság és az erkölcs viszonylatában pedig további kérdés a gazdasági tevékenység erkölcsi normáinak létezése. A vállalkozások versenyképességét szűkítheti az etikai szabályok kikerülése, a korrupció széles eszköztárát előny megszerzése vagy fennmaradásuk érdekében felhasználják fel.

Felhasznált irodalom

[1.] Borbás L(2011) Comments ont he Review of the „Small Business Act for Europe”. A Hungarian viewpoint. 9th MEB International Conference Proceedings pp. 229-237

[2.] 2009.october.) Európai Csalásellenes Hivatal (OLAF) 2012 éves jelentése

a. http://ec.europa.eu/anti_fraud/about-us/reports/olaf-report/index_en.htm

[3.] Lackó Mária (2008) Az adóráták és a korrupció hatása az adóbevételre-nemzetközi összehasonlítás

[4.] MTA Közgazdaságtudományi Intézet 2008 Múhelytanulmány MT-DP-2008/08

[5.] Hegedűs M. (2012) A kisvállalkozói attitúd sajátos vonásai.

a. Könyvvizsgálók lapja 2012. I évfolyam 7-8 szám 10-12 pp. 
[6.] Hegedűs M (2013) Increasing of corruption and trickery in economy during crisis period

[7.] Selye János Egyetem 2013

[8.] Nemzetközi Tudományos Konferenciájának tanulmánykötetet 106-122 oldal

[9.] PricewaterhouseCoopers (2009) Globális gazdasági bűnözés

[10.] http://www.pwc.com/en_HU/hu/publications/assets/PwC-GlobalEconomicCrimeSurvey-HU2009-HUOK.pdf

[11.] Transparency International Corruption Perceptions Index 2012

a. http://www.transparency.org/cpi2012/results

[12.] Szvetlana P. Glinkina [2010] A korrupció, mint jelenség: elmélet és oroszországi gyakorlat

[13.] Eszmélet Társadalomkritikai és kulturális folyóirat 2010. 85.szám 116-156 oldal

[14.] VISA The Shadow Economy in Europe; 2013

[15.] http://www.visaeurope.com/en/about_us/industry_insights.aspx 